\title{
Correction to: Implementation of RTO in a large hydrogen network considering uncertainty
}

\author{
Anibal Galan ${ }^{1,2}$ (D) $\cdot$ Cesar de Prada ${ }^{1,2}$ (D) $\cdot$ Gloria Gutierrez $^{1,2} \cdot$ Daniel Sarabia $^{2,3}$ (D) \\ Ignacio E. Grossmann ${ }^{4}$ (D) $\cdot$ Rafael Gonzalez ${ }^{5}$
}

Published online: 20 June 2019

(c) The Author(s) 2019

\section{Correction to: Optimization and Engineering https://doi.org/10.1007/s11081-019-09444-3}

In the original publication of the article, in Table 4 and Table 5 lower case ' $k$ ' which is the correct convention of the units was published as upper case ' $\mathrm{K}$ '.

The corrected tables are provided below.

The original article can be found online at https://doi.org/10.1007/s11081-019-09444-3.

Anibal Galan

anibalsantiago.galan@uva.es

1 Department of Systems Engineering and Automatic Control, University of Valladolid, 47011 Valladolid, Spain

2 Institute of Sustainable Processes, University of Valladolid, 47011 Valladolid, Spain

3 Department of Electromechanical Engineering, Escuela Politécnica Superior, University of Burgos, 09006 Burgos, Spain

4 Center for Advanced Process Decision-making, Department of Chemical Engineering, Carnegie Mellon University, Pittsburgh, PA 15213, USA

5 Departamento Optimización y Control, Petróleos del Norte S.A., 48550 Muskiz, Spain 
Table 4 Results of the implementation of the TSS formulation over the typical stochastic assumptions, i.e.: perfect information (PI), recourse problem (RP), expectation of the expected value problem (EEVP)

\begin{tabular}{|c|c|c|c|c|c|c|}
\hline PI & $\mathrm{RP}$ & EEVP & EVPI & & VSS & \\
\hline $\mathrm{k} € / \mathrm{h}$ & $\mathrm{k} € / \mathrm{h}$ & $\mathrm{k} € / \mathrm{h}$ & $\mathrm{k} € / \mathrm{h}$ & $\%^{a}$ & $\mathrm{k} € / \mathrm{h}$ & $\%^{\mathrm{a}}$ \\
\hline 737.176 & 735.936 & 725.014 & 1.240 & 0.17 & 10.923 & 1.51 \\
\hline
\end{tabular}

These are used to calculate EVPI and VSS as suggested by Birge and Louveaux (2011)

${ }^{\text {a }}$ Percentage w.r.t. EEVP

Table 5 Results of CVaR, VaR and hydrogen plant $\mathrm{H} 4$ at confidence levels $95 \%$ and $99 \%$

\begin{tabular}{llllll}
\hline Confidence $(1-\alpha)$ & $\mathrm{CVaR}_{1-\alpha}$ & $\mathrm{VaR}_{1-\alpha}$ & $\mathrm{H} 4$ & $\%^{\mathrm{a}}$ & Time \\
$\%$ & $\mathrm{k} € / \mathrm{h}$ & $\mathrm{k} € / \mathrm{h}$ & $\mathrm{Nm}^{3} / \mathrm{h}$ & $\mathrm{CPU}^{\mathrm{b}} \mathrm{s}$ \\
\hline 95 & 735.88 & 735.88 & $37,884.06$ & 86.10 & 71.46 \\
99 & 735.88 & 735.88 & $37,884.06$ & 86.10 & 43.74 \\
$0^{\mathrm{c}}$ & $\mathrm{NA}^{\mathrm{d}}$ & $\mathrm{NA}^{\mathrm{d}}$ & $37,066.68$ & 84.24 & 0.92 \\
\hline
\end{tabular}

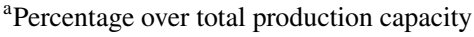

${ }^{\mathrm{b}}$ Intel ${ }^{\circledR}$ Core $^{\mathrm{TM}}$ i7 $2.50 \mathrm{GHz}$ and $16.0 \mathrm{~GB}$ of RAM

${ }^{c}$ Risk-neutral solution (i.e.: $\alpha=1$ ), RP solution

${ }^{\mathrm{d}}$ Not applicable

Open Access This article is distributed under the terms of the Creative Commons Attribution 4.0 International License (http://creativecommons.org/licenses/by/4.0/), which permits unrestricted use, distribution, and reproduction in any medium, provided you give appropriate credit to the original author(s) and the source, provide a link to the Creative Commons license, and indicate if changes were made.

Publisher's Note Springer Nature remains neutral with regard to jurisdictional claims in published maps and institutional affiliations. 